\title{
EDITORIALS
}

\section{THE QUEST}

The PRACTICE of anaesthesia is an imprecise art, and, were it not so essential and indispensable a part of modern medical practice, it might be questioned whether so empirical a procedure would be scientifically or even ethically permissible.

When one considers that the site or action of general anaesthetics is largely unknown, save that the central nervous system is certainly involved and, furthermore, that the mode of action is conjectural and that such physical phenomena as pressure reversal are both intriguing and at the same time puzzling in the context of shedding some light on the possible mechanisms by which inhalational agents act upon cells, then the dispassionate observer is left wondering at the temerity of the practitioners of this arcane art.

Or, more truly, this would be the position of the naive observer who failed to see the situation in its practical light. General anaesthetics do work. Patients recover successfully from periods of oblivion brought about by their use and the state of general anaesthesia appears to be produced quite safely, if empirically, and to permit surgical procedures to be performed in comfort for the patient and in ideal conditions for the surgeon.

That something can be done to sick people with apparent impunity to their ultimate benefit is argument enough for the employment of a technique or procedure, albeit the mechanisms of action are unknown or, as in the case of surgical anaesthesia, the precise state that is produced is ill-understood. However, it is not sufficiently cogent an argument to permit a ready and uncritical acceptance of both the practice and the dogma which attends the repeated practice of such techniques. Particularly is this passive acceptance to be deprecated and even condemned when means present themselves for the further investigation of those practices and techniques whose scientific foundations remain shaky and principles empirical.

Some of the investigative tools with which the mysteries may be studied and the dogmas debated and subjected to that challenge that all dogma demands, are no more recondite than an enquiring mind. Others are more complicated and technical. The practising anaesthetist has an enquiring mind; at least, let us say, he has an enquir-

\section{L'INTERROGATION}

L'ADMINISTRATION DE L'ANESTHÉSIE relève d'un art à l'imprécision notoire et n'était-ce de son indispensabilité quotidienne, on serait justifié de se demander si une discipline aussi empirique est aujourd'hui scientifiquement admissible ou même moralement permissible.

Il faut bien reconnaitre que le site d'action des agents anesthésiques généraux est pratiquement inconnu sauf pour le système nerveux central dont on sait qu'il est certainement impliqué, en outre, le mode d'action de ces agents relève pour le moment de la conjecture; à ce chapitre, le renversement des pressions est un phénomène physique sans doute intéressant mais du même coup embarrassant dans cette recherche d'une explication du mécanisme d'action des agents anesthésiques au niveau cellulaire.

Devant de telles constatations, l'observateur objectif ne peut que s'étonner de la témérité de ces "praticiens de l'incertitude". Ou plus justement, ce serait là l'étonnement d'un observateur' théoricien qui manquerait de voir l'aspect pragmatique de la situation. Car, les anesthésiques généraux agissent. Une inconscience réversible accompagne leur emploi et cet état d'anesthésie générale, apparemment sécuritaire en dépit de l'empirisme qui l'accompagne, permet l'exécution d'opérations chirurgicales sans douleur pour le malade et dans des conditions de travail idéales pour le chirurgien.

Toute technique ou intervention qui, sans danger apparent, contribue au bien-être du malade, s'en trouve ainsi cautionnée mème si le mécanisme d'action et, dans le cas de l'anesthésie l'état produit, sont encore en bonne partie inconnus. Cependant, on ne saurait, par la seule force ce cet argument, accepter sans critique aucune l'exercice de l'anesthésie et le dogmatisme qui accompagne la pratique répétée de ses procédés. Il s'impose d'autant plus de désavouer ou même de condamner une telle attitude passive que des moyens sont maintenant disponibles pour pousser plus loin l'interrogation sur ces pratiques et techniques dont les assises scientifiques sont encore incertaines et les principes empiriques. Plusieurs de ces mystères qu'on doit chercher à élucider et ces dogmes qu'on doit remettre en question n'exigent rien de plus qu'un esprit curieux. D'autres sont plus 
ing mind if he is a good and competent practising anaesthetist. Since in his daily practice of the pharmacological disruption of physiological systems his very raison d'etre is the studying and the interpretation of the response of those systems to his pharmacological interference. What does this demand more than an enquiring mind?

For those studies or for the answering of those questions for which more technical machinery is necessary, the anaesthetist need not be deterred from posing the questions and seeking answers to them. The world abounds in machines, and technologists are not hard to come by.

However, as with nearly everything else in life, it is the first step that counts. First steps are by their very nature almost always simple ones. The gavotte and minuet come later.

No matter that the first questions we may pose have already been asked and apparently answered elsewhere. Have they indeed been answered? How valid is the answer? Has the answer been so well accepted that it has become dogma? If this is the case, then the enquiring mind is in luck indeed, for Holy Writ is often wrong in part or whole, and there is no more attractive target for the enquiring practitioner.

A word of caution is in order.

It pays to know what dogma really says - in other words, know the liturgy before you challenge its validity. After that, go questing. The hunt is on and let slip the dogs of reason.

The clinical practice of anaesthesia abounds, nay, is replete with questions which need answers. The very fact that we generally manage things pretty well does blind us often to the possibility that some of what we do may be irrelevant and perhaps dangerous and that we could do better. One should remember that the clinical practice of anaesthesia is what all our research, our studies, our questions and our publications are about. That's what we are here for. We are all in the trade of making sick folk better and, scientific as we may and should be, we must not forget that end to which we work.

This means that the clinical anaesthetist is perhaps the most fortunate of medical mortals. $\mathrm{He}$ is both practitioner and scientific investigator. Every anaesthetic is, of its very nature, a pharmacological experiment. In parenthesis, perhaps we may be permitted to add that no experiment is any better than the records that are kept of it and, as clinical scientists, we anaesthetists are often open to criticism in the matter of keeping our own scientific records - quite apart from the ones that are required for departmental and accreditation compliqués et comportent un aspect technique important. L'anesthésiste possède cette qualité. tout au moins disons que son esprit est tel, s'il est un bon anesthésiste, un praticien compétent, conscient de la postée de son intervention sur l'équilibre des systèmes physiologiques. L'observation de la réponse de l'organisme et son interprétation constituent en somme sa raison d'être. Que faut-il de plus pour cela qu'un esprit éveillé?

Pour ces problèmes qui comportent un volet technique important, l'anesthésiste ne doit pas s'interdire de poser des questions et de chercher des réponses: le monde déborde de machines et d'instruments et les techniciens sont nombreux pour l'assister dans cette démarche.

En ceci comme en toute chose, c'est le premier pas qui compte et par sa nature même le premier pas est toujours simple; la gavotte et le menuet ne viennent jamais que plus tard. Il importe peu que la première question qu'on se pose ait déjà été soulevée et ait apparemment trouvé sa réponse. D'ailleurs, cette prétendue réponse est-elle valide? L'a-t-on tellement bien reçue qu'elle soit maintenant devenue un dogme? $S$ 'il en est ainsi, c'est que la chance sourit à l'esprit curieux car les Saintes Ecritures elles-mêmes sont souvent erronées et il n'y a pas de plus belle cible pour le praticien iconoclaste

Un mot d'avertissement est de mise ici: cherchez bien ce que le dogme veut vraiment dire, en d'autres mots, dépouillez-le de son rituel avant d'en contester la validité. Ensuite, en avant pour la chasse, libérez les meutes de la raison.

L'anesthésie clinique abonde, mieux encore déborde de questions en mal de réponses. Notre apparente efficacité même nous aveugle fré. quemment et nous empêche de penser que cerlains de nos gestes sont inutiles et même peut-être dangereux et qu'on pourrait faire mieux. Faut-il rappeler qu'en dernière analyse, c'est lanes. thésie clinique elle-même qui est l'ultime bénéficiaire de nos recherches, études, publications et autres travaux. C'est pour elle que nous sommes là.

Notre métier est d'améliorer la santé des gens malades et tout scientifiques que nous soyions ou voulions être, cet objectif doit être gardé bien en vue.

Ceci entraîne que l'anesthésiste clinicien est peut-être le plus heureux des mortels en médecine. Il combine l'exercice clinique à la recherche scientifique: toute anesthésie est par son essence même une expérience en pharmacologie. Incidemment, peut-être nous autorise-t-on à ajou- 
purposes. Indeed, one knows only too well how little those latter really tell of the actual and important peri-anaesthetic events. For example, how few hospital charts record anywhere the success or otherwise of the pre-anaesthetic medication. The clinician scientist will record this in his own little black book.

Pre-anaesthetic medication, induction techniques, effects of endotracheal intubation in the very lightly anaesthetized state where this mancuvre is often carried out; a whole host of simple but important clinical questions present themselves for study. Perhaps these questions can never be answered in the sense of a definitive or final answer. Perhaps this is as it should be. Definitive answers have a habit of breeding dogma. Nonetheless, the questions remain and cry for study.

Not to accept this challenge is both wrong and tragic. Wrong for the practitioner and tragic for the practitioner and patient. The practitioner is denied the stimulus of the question and the patient deprived of the benefits of both the quest and perhaps the answer.

K.M. LEIGHTON

ter qu'une expérience ne vaut que par la qualité des dossiers qu'on en conserve et qu'à ce sujet, nous, anesthésistes, comme scientifiques, donnons prise à la critique. Indépendamment des prérequis $\mathrm{d}^{\top}$ agrément, nos dossiers sont loin d'avoir l'étoffe de documents scientifiques. On sait trop bien le peu de renseignements qu'on peut en tirer plus tard sur les événements du moment qui ont entouré la période anesthésique. Par exemple, peu de mémoires de protocoles d'anesthésie prévoient l'entrée des effets de la prémédication; le clinicien scientifique pour sa part inscrira cette importante donnée dans ses propres dossiers.

La médication plé-anesthésique, les techniques d'induction, les conséquences de l'intubation endotrachéale sous anesthésie légère comme il est d'usage de le faire, voilà toute une collection de questions simples mais importantes qui surgissent d'elles-mêmes en quête d'une réponse. Peut-être n'en trouverone-elles jamais une qui soit définitive; il est probablement bon qu'il en soit ainsi car les affirmations définitives ont la mauvaise habitude d'engendrer le uogmatisme. Quoi qu'il en soit, ces interrogations demeurent et nous pressent.

On aurait tragiquement tort de rejeter ce défi: tort pour le praticien et tragédie pour lui et pour son malade car le médecin se prive ainsi de l'aiguillon intellectuel de la question et le malade se voit interdire les bénéfices de la démarche et peut-ètre de son aboutissement.

K.M. LEIGHTON

\section{LE SYSTEME INTERNATIONAL DES UNITES DE MESURES}

\section{SYSTEME INTERNATIONAL (S.I.) UNITS}

STARTING WITH volume 24 a policy, previously agreed to by the Editorial Board of this Journal, was implemented by which conventional units of measurement are now being accompanied by the appropriate S.I. Units, the International System of Units of Measurement. The question has been raised by readers why it should be necessary to be encumbered by these new designations when the old ones are serving us well. In introducing S.I. Units, this Journal is not unique, nor indeed has it been unduly hasty, but is acting on the policy advocated by the World Health Organization only after an increasing number of bodies have taken similar steps. To quote the March 1978 issue of the W.H.O. Chronicle: "It is imperative that, with the least possible delay, all members of the medical and allied professions in all countries
AVEC la publication du vingt-quatrième volume du Journal, la Rédaction introduisait sa nouvelle politique d'implantation du système international des unités de mesures en adjoignant aux unités conventionnelles les unités correspondantes du système international. Certains de nos lecteurs se sont demandés s'il valait la peine de s'encombrer d'une nouvelle terminologie alors que l'ancienne nous servait si bien. En réalité, en agissant ainsi, notre journal était loin de faire cavalier seul on preuve de hâte excessive mais tout simplement se ralliait à la politique de l'Organisation Mondiale de la Santè à la suite d'un nombre croissant d'institutions. Le numéro de mars 1978 des chroniques O.M.S. exprimait bien la nécessité et l'urgence pour tous les membres des professions médicales et para- 
of the world should change over to S.I. Units, so that there will be world-wide agreement and conformity in this important aspect of health work."

No one can deny that a universal system will indeed be of great advantage, and it is beside the point whether the units chosen are or are not ideal ones. Men much more qualified than this writer (and most if not all of our readers) have made their choice, and it must have been obvious to them at the time that introduction of this system would require a great deal of re-learning and adjustment by the scientific community. But this was obviously considered to be an acceptable price to pay for the eventual advantages inherent in a system which everyone can understand, irrespective of country and language. It is anticipated that, after a few ycars of using dual designations, conventional units will be phased out altogether. There is no way in which this Journal can stay aloof of a convention arrived at internationally and agreed to by Canada as a member nation of W.H.O. médicales à l'échelle mondiale de se convertir aux unités internationales afin que l'entente et l'uniformité puissent s'imposer dans l'important domaine du travail sanitaire.

Personne ne peut fermer les yeux sur les avantages d'un système univer'sel et l'aspect le plus important du problème n'est peut-être pas de savoir si oui ou non nous avons atteint le système idéal. Des personnes beaucoup mieux qualifiées que celui qui signe cet éditorial (et ceci s'applique à la plupart sinon à tous nos lecteurs) ont déjà fait un choix et il a dû leur paraître évident à ce moment-là que ce changement nécessiterait un certain degré de rééducation et de rajustement pour une grande partie de la communauté scientifique. Mais on a jugé bon que c'était un prix acceptable à payer pour obtenir des bienfaits inhérents à un système compris par chacun malgré sa langue ou son pays. Ce n'est pas trop anticiper que de croire que l'utilisation conjointe des deux dénominations pendant quelques années nous permettra éventuellement de laisser tomber les unités conventionnelles. II est donc impensable pour le Journal de demeurer à l'écart d'une entente internationale déjà paraphée par le Canada en tant que membre de l'O.M.S.

GORDON M. WYANT 